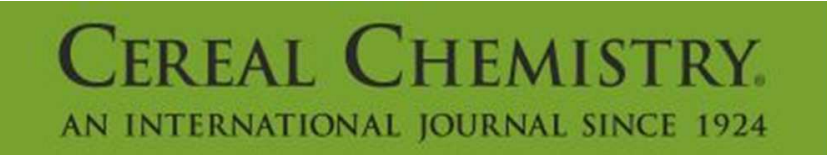

\title{
Structural modification of gluten proteins in strong and weak wheat dough as affected by mixing temperature
}

\begin{tabular}{|r|l|}
\hline Journal: & Cereal Chemistry \\
\hline Manuscript ID & CCHEM-06-15-0123-R.R2 \\
\hline Danuscript Type: & Research \\
\hline Complete List of Authors: & $\begin{array}{l}\text { Quayson, Enoch; University of Minnesota, Department of Food Science and } \\
\text { Nutrition } \\
\text { Marti, Alessandra; University of Milan, DeFENS, Department of Food, } \\
\text { Environmental and Nutritional Sciences } \\
\text { Bonomi, Francesco; University of Milan, } \\
\text { Atwell, William (Bill); University of Minnesota, Department of Food Science } \\
\text { and Nutrition } \\
\text { Seetharaman, Koushik; University of Minnesota, Food Science and } \\
\text { Nutrition }\end{array}$ \\
\hline Area of Expertise: & \begin{tabular}{l} 
Dough, Flour, Protein, Gluten \\
\hline
\end{tabular} \\
\hline
\end{tabular}


1

2

3

4

5

6

7

8

9

10

11

12

13

\section{Structural modification of gluten proteins in strong and weak wheat dough as affected by}

\section{mixing temperature}

3

Enoch T. Quayson ${ }^{1}$, Alessandra Marti ${ }^{1,2, *}$, Francesco Bonomi $^{2}$, William Atwell ${ }^{1}$ and Koushik Seetharaman ${ }^{3}$

1. Department of Food Science and Nutrition, University of Minnesota, St. Paul. MN USA.

7 2. Department of Food, Environmental and Nutritional Sciences, University of Milan, Italy.

3. Deceased; formerly, Department of Food Science and Nutrition, University of Minnesota, St.

9 Paul, MN.USA.

1 *Corresponding author: $\quad$ Phone +1 612625 2768. Fax +1 612 625-5272.

E-mailamarti@umn.edu; alessandra.marti@unimi.it 


\section{Abstract}

15 The effect of temperature $\left(\geq 25^{\circ} \mathrm{C}\right)$ on dough rheological properties and gluten functionality have 16 been investigated for decades, but no study has addressed the effect of low temperature $\left(<30^{\circ} \mathrm{C}\right)$ on 17 gluten network attributes in flours with strong and weak dough characteristics. This study monitored 18 changes in protein extractability in presence and absence of reducing agents, the content in readily 19 accessible and SDS-accessible thiols, and the secondary structural features of proteins in doughs 20 from commercial hard wheat flour (HWF) and soft wheat flour (SWF) mixed at 4, 15 , and $30^{\circ} \mathrm{C}$. 21 SWF mixed at 4 and $15^{\circ} \mathrm{C}$ showed similar mixing properties as $\mathrm{HWF}$ mixed at $30^{\circ} \mathrm{C}$ (which is the 22 standard temperature). The effect of mixing temperature is different at the molecular level between 23 the two flours studied. Protein features of HWF did not change as mixing temperature decreased, 24 with the only exception for an increase in SDS-accessible thiols. Decreasing mixing temperature for 25 SWF caused an increase in SDS-protein solubility and SDS-accessible thiols, and an increase in $\beta$ 26 turns structures at the expense of $\beta$-sheet structures. Thus, non-covalent interactions appear to drive 27 protein network at low temperatures $\left(4^{\circ} \mathrm{C}\right.$ and $\left.15^{\circ} \mathrm{C}\right)$ while covalent interactions dominate at 28 standard mixing $\left(30^{\circ} \mathrm{C}\right)$ in doughs from both flours.

Keywords: wheat dough, mixing temperature, protein conformation, protein solubility, thiols 31 
32 Common wheat (Triticum aestivum) is the most versatile cereal since the flour from the grains can 33 successfully be transformed into a large number of products - bread, cookies, biscuits, cakes - that 34 are highly diverse in their palatability, structure and consumption occasions. The success of wheat is 35 due to the capacity of its storage proteins to interact and develop the gluten network, which is the 36 framework of all bakery products.

37 The functionality of gluten in defining product attributes differs based on ingredient 38 formulation and processing conditions. However, regardless of the product formulation and 39 processing condition, gluten formation is the key step for the preparation of cereal-based products. 40 During mixing, the solvated proteins become flexible enough to undergo further structural 41 modifications upon kneading. In most cases, kneading results in a rearrangement of the pattern of 42 two major types of interactions: disulfide bridges and hydrophobic contacts between surface43 exposed regions (Bonomi et al 2014). It has recently been shown that gluten network formation is 44 inherently different at the molecular level between soft and hard wheat flours. Development of a 45 network in hard wheat dough appears to be driven more by disulfide linkages, whereas the network 46 in soft wheat dough is governed primarily by hydrophobic interactions (Jazaeri et al 2015).

47 Obtaining the highest number of interaction among proteins requires a control of mixing 48 conditions, as over-kneading weakens the interactions among proteins and the strength of the gluten 49 network. This occurs as a consequence of the conversion of relatively rigid elements of secondary 50 structure (e.g. $\alpha$-helices and $\beta$-sheets) into random coil structures that do not contribute to the 51 strength of the overall gluten network (Bonomi et al 2014; Robertson et al 2007). Moreover, it has 52 been suggested that during mixing, the size of protein aggregates decreases (Mecham et al 1965; 53 Tsen 1967) as a consequence of physical separation of the aggregates (Tsen 1967). This has been 
54 suggested to involve breakdown of either non-covalent interactions (Tsen 1967) or of covalent bonds 55 (Tanaka and Bushuk 1973; MacRitchie 1975; Graveland et al 1980; Danno and Hoseney 1982). Baking performance of wheat flours strongly depends on the mixing conditions. Best results

57 in terms of bread volume are obtained when the dough is mixed to optimum consistency at standard 58 speed $(63 \mathrm{rpm})$, instead of mixing the dough at high speed $(1,250 \mathrm{rpm})$ with a fixed time $(1 \mathrm{~min})$ 59 (Thanhaeuser et al 2014). In regards of mixing temperature, $29{ }^{\circ} \mathrm{C}$ and $30{ }^{\circ} \mathrm{C}$ are the AACC standard 60 temperatures for straight dough bread-making (AACCI 10-10.03) and for the farinograph test 61 (AACCI 54-21.02), respectively. Although these conditions are important in providing the right 62 environment for enzymes that are important to the various biochemical reactions required to produce 63 the desired end result, doughs mixed at $30{ }^{\circ} \mathrm{C}$ appear underdeveloped and give poor baking results 64 (Kieffer et al. 1998). Thus, mixing at $22{ }^{\circ} \mathrm{C}$ is indicated as preferable by some Authors (Kieffer et al 65 1998; Thanhaeuser et al 2014). Doughs mixed at temperatures lower than $30{ }^{\circ} \mathrm{C}$ require longer 66 mixing to achieve the same development stage as for conventional dough mixed at $30^{\circ} \mathrm{C}(\mathrm{Basaram}$ 67 and Gocmen 2003; Thanhaeuser et al 2014). Moreover dough production at low temperatures 68 necessitates additional expense to maintain the temperature such as water jackets, pre-chilling of 69 flour, and cooler ambient temperature. On the other hand, the dough is less sticky and the resulting 70 bread shows higher loaf specific volume and better grain texture in comparison to conventional 71 mixing conditions (Basaram and Gocmen 2003; Thanhaeuser et al 2014).

72 To the best of our knowledge, this is the first study to evaluate the effects of mixing 73 temperatures $\left(4,15\right.$, and $\left.30^{\circ} \mathrm{C}\right)$ on protein structural characteristics of hard and soft wheat flour 74 doughs. The objective of this research was to evaluate protein solubility, thiols content, protein 75 conformation, and farinograph characteristics of hard and soft wheat flours at various mixing 76 temperatures. Studying such molecular parameters could lead to a more complete understanding of 
77 the role of mixing temperature on the formation of the gluten network in functionally contrasting 78 flours.

79

\section{MATERIALS AND METHODS}

81

82 Flours. Commercial soft (SWF, proteins: $9.0 \pm 0.1 \mathrm{~g} / 100 \mathrm{~g}_{\mathrm{d} . b .}$ ) and hard (HWF, proteins: $13.04 \pm 0.06$ $83 \mathrm{~g} / 100 \mathrm{~g}_{\mathrm{d} . b .}$ ) wheat flours, for biscuit- and bread-making respectively, were kindly provided by 84 Horizon Milling LLC (Mankato, MN, USA). Protein content $(\mathrm{N} \times 5.7)$ was determined according to 85 AACC approved method (AACC 46-30.01).

86

87 Chemicals. All chemicals were of analytical grade, unless otherwise stated. Deuterium oxide $\left(\mathrm{D}_{2} \mathrm{O}\right)$, 88 dithiothreitol (DTT), disodium hydrogen phosphate, sodium dihydrogen phosphate, and 5,5' 89 dithiobis (2-nitrobenzoate) (DTNB) were from Sigma Aldrich, (St Louis, MO, USA). Sodium 90 chloride $(\mathrm{NaCl})$ was from Fisher Scientific (Fair Lawn, NJ, USA), and sodium dodecyl sulfate 91 (SDS) from Life Technologies (Grand Island, NY, USA). A RC-DC (reducing compatible and 92 detergent compatible) Protein Assay for determining protein concentration was from Bio-Rad 93 (Hercules, CA, USA).

95 Dough Preparation. Dough samples from both strong (HWF) and weak (SWF) flours were 96 prepared at three temperatures $\left(4,15\right.$, and $\left.30^{\circ} \mathrm{C}\right)$ in a Farinograph-AT (C.W. Brabender Inc., 97 Hackensack, NJ, USA) equipped with a $50 \mathrm{~g}$ mixing bowl. All the samples were prepared at the 98 optimal water absorption, which is the amount of water to add to $100 \mathrm{~g}$ of flour to attain a 99 consistency of 500 \pm 20 Farinograph Unit (FU). The mixing bowl was kept at the desired temperature 100 by means of a temperature controlled water bath attached to the farinograph. Mixing water was 
101 delivered at the desired temperature. Dough samples for analyses were collected at dough 102 development time, which is the time from first addition of water to the point of maximum 103 consistency range. Each dough sample was prepared in duplicate. Samples were collected with 104 minimal additional physical manipulation. The fresh dough was used as is for protein conformation 105 spectroscopic studies. For protein solubility, and for measuring readily accessible and SDS106 accessible thiols, the samples were immediately transferred to liquid nitrogen and lyophilized. The 107 freeze-dried samples were then ground using a pestle and mortar to a powder (particle size $<0.5$ $108 \mathrm{~mm})$.

109

110 Protein Solubility. Protein solubility in the freeze-dried dough was determined following the 111 method of Jazaeri et al (2015) with little modification. Soluble proteins were extracted at $25^{\circ} \mathrm{C}$ in $1120.05 \mathrm{M}$ sodium phosphate buffer of $\mathrm{pH} 7.0$ with $0.1 \mathrm{M} \mathrm{NaCl}$ and $1 \% \mathrm{SDS}(\mathrm{w} / \mathrm{v})$ in presence or 113 absence of $10 \mathrm{mM}$ DTT. A $1 \mathrm{ml}$ volume of the buffer was added to $10 \mathrm{mg}$ of sample and mixed on 114 shaker for $60 \mathrm{~min}$ at $25^{\circ} \mathrm{C}$. After centrifugation at $10,000 \times \mathrm{g}$ for $5 \mathrm{~min}$, the amount of protein in the 115 supernatant $(100 \mu \mathrm{l})$ was determined spectrophotometrically using the RC-DC Protein Assay, which 116 is based on the Lowry assay (Lowry et al 1951). Bovine serum albumin was used as standard and 117 results (average of four determinations) were expressed as $\mathrm{mg}$ soluble protein/g protein.

119 Readily Accessible and SDS-Accessible Thiols. Readily accessible thiols (SH) were determined 120 following the method of Iametti et al (2006). An aliquot (100 mg) of sample was suspended in $5 \mathrm{~mL}$ 121 of buffer $(0.05 \mathrm{M}$ sodium phosphate, $0.1 \mathrm{M} \mathrm{NaCl}, \mathrm{pH} 7.0)$ containing $0.5 \mathrm{mM}$ DTNB. The 122 suspension was incubated at $25^{\circ} \mathrm{C}$ for $60 \mathrm{~min}$ and centrifuged at $10,000 \mathrm{~g}$ for $3 \mathrm{~min}$. The supernatant 123 was subsequently filtered using Fisher Scientific filter paper (particle retention in the range of $5-10$ $124 \mu \mathrm{m}$; Pittsburgh, PA, USA), and the absorbance was read at $412 \mathrm{~nm}$. SDS-accessible thiols were 
125 determined by the same method but in presence of $1 \%$ SDS (w/v) in the suspension buffer. The 126 amounts of readily accessible and SDS-accessible thiol groups were calculated using the extinction 127 coefficient of $14150 \mathrm{M}^{-1} \mathrm{~cm}^{-1}$ (Eyer et al 2003) and the average of four determinations was reported. 128

134 an average of 32 scans at $4 \mathrm{~cm}^{-1}$ resolution. Background spectrum of the empty trough sampling 135 plate was collected before each sample. A minimum of 4 spectra per sample was used for spectral 136 analysis. Spectra were collected within 10 minutes of sample preparation in order to limit molecular 137 and structural changes as much as possible. The sample was pressed firmly onto the crystal to 138 eliminate air and to achieve the best possible contact. Spectral analysis was performed by using 139 OPUS software v. 7.0 according to Bock and Damodaran (2013). Reference $\mathrm{H}_{2} \mathrm{O}-\mathrm{D}_{2} \mathrm{O}$ mixtures 140 matched to the moisture content of the dough samples ( 45 for all the samples except for dough $141 \mathrm{HWF}$ at $4^{\circ} \mathrm{C}$, whose moisture was $\sim 50 \%$, Table I) were collected and vector-normalized. The 142 difference of the vector-normailzed spectra obtained in the $3000-3800 \mathrm{~cm}^{-1}$ region were analyzed 143 for changes in state of water structure in dough compared with the reference state in the $\mathrm{H}_{2} \mathrm{O}-\mathrm{D}_{2} \mathrm{O}$ 144 mixture following the approach used by Bock and Damodaran (2013). The reference $\mathrm{H}_{2} \mathrm{O}-\mathrm{D}_{2} \mathrm{O}$ 145 mixtures were also used for subtraction of water contributions in the amide I region $(1600-1700$ $146 \mathrm{~cm}^{-1}$ ) of the vector-normalized spectra. The quantitative estimation of protein secondary structure in 147 the amide I region of dough was based on second derivative spectra using a five-point Savitsky148 Golay function as described by Bock and Damodaran (2013). The spectral regions were assigned as 
$1491620-1644,1644-1652,1652-1660$ and $1660-1685 \mathrm{~cm}^{-1}$ for $\beta$-sheets, unordered, $\alpha$-helix, and $\beta$-turn 150 structures respectively. The second derivative area for each secondary structural region was divided 151 by the total area of the amide I region.

152

153 Statistical Analysis. Dough samples were prepared in duplicate. For each subsample, protein 154 solubility, readily and SDS-accessible thiols, and ATR-FTIR analyses were carried out in duplicate. 155 Analysis of variance (ANOVA) was performed utilizing Statgraphics XV version 15.1.02 (StatPoint Inc., 156 Warrenton, VA, USA). Mixing temperature and/or type of secondary structures were used as factor. When 157 a factor effect was found significant $(\mathrm{p} \leq 0.05)$, significant differences among the respective means were 158 determined using Fisher's Least Significant Difference (LSD) test.

\section{RESULTS AND DISCUSSION}

160 Mixing Properties of Flours. Mixing properties of SWF and HWF flours as affected by mixing 161 temperature $\left(4,15\right.$, and $\left.30^{\circ} \mathrm{C}\right)$ are shown in Fig. $1 \mathrm{~A}$ and $1 \mathrm{~B}$, respectively. The farinograph indices 162 obtained from the curves are summarized in Table I. At $30^{\circ} \mathrm{C}$ - which is the standard temperature 163 according to the AACC official method - the HWF exhibited higher water absorption $(64.7 \%$ vs $16455.5 \%)$, longer dough development time (2.13 $\mathrm{min} v s 1.03 \mathrm{~min})$ and greater stability (15 $\min v s 1.1$ $165 \mathrm{~min}$ ) than the SWF. Regardless of the type of flour, as the temperature decreased from 30 to $4{ }^{\circ} \mathrm{C}$, 166 the optimal water absorption increased (Table I). As expected, a decrease in temperature increased 167 dough consistency, and thus, higher amounts of water were required to obtain the desired dough 168 consistency $(500 \pm 20 \mathrm{FU})$. Decreasing mixing temperature also resulted in an increase in dough 169 development time and dough stability (Table I).

170 In general, long dough development time is undesirable because it means longer processing 171 time and increased energy requirements for dough mixing. On the other hand, low temperatures 
172 increased dough stability and thus improves dough handling. Our results on mixing properties are

173 similar to those obtained by Basaran and Gocmen (2003) who investigated the role of mixing 174 temperature $\left(17,23\right.$ and $\left.30^{\circ} \mathrm{C}\right)$ on dough mixing and bread characteristics. Interestingly, at low 175 temperature $\left(4^{\circ} \mathrm{C}\right.$ and $\left.15^{\circ} \mathrm{C}\right)$, SWF showed a mixing profile very similar to that of $\mathrm{HWF}$ at $30^{\circ} \mathrm{C}$. 176

177 Protein Solubility. Protein solubility gives insight on the type of protein interactions occurring in 178 flour or dough. The extent of contribution of hydrophobic and covalent interactions to protein 179 network stabilization can be determined by adding detergents (e.g SDS) or reducing agent (e.g. 180 DTT) respectively to the extraction buffer (Iametti et al 2006, 2012; Lagrain et al 2007; Bonomi et al 181 2012). Protein solubility of SWF and HWF dough as affected by mixing temperature is shown in 182 Fig. 2. When the flours were mixed into dough to the point of maximum dough development at the 183 standard temperature $\left(30^{\circ} \mathrm{C}\right)$, a decrease in SDS-protein solubility was observed for both $\mathrm{SWF}$ 184 (from $693.87 \pm 72.2$ - data not shown - to $425.02 \pm 126.23 \mathrm{mg} / \mathrm{g}$ protein, in flour and dough, 185 respectively) and HWF (from $811.33 \pm 4.0$ - data not shown - to $509.8 \pm 86.33 \mathrm{mg} / \mathrm{g}$ protein, in flour 186 and dough, respectively), in agreement with previous studies (Jazaeri et al 2015; Hayta and 187 Schofield 2004). The formation of a developed gluten network decreases the amount of SDS-soluble 188 proteins due to the increased protein-protein interaction. At $30^{\circ} \mathrm{C}$, the two dough samples did not 189 show statistically significance difference $(\mathrm{p} \leq 0.05)$ in SDS-protein solubility (HWF: $509.8 \pm 86.33$ $190 \mathrm{mg} / \mathrm{g}$ protein; SWF: $425.02 \pm 126.23 \mathrm{mg} / \mathrm{g}$ protein). Jazaeri et al (2015) and Kuktaite et al (2004) 191 found dough from weak flours to have higher SDS-protein solubility than dough from strong flours 192 at optimal mixing time. Similarly, Hayta and Schofield (2004) found extracted gluten from strong 193 flour to have significantly lower SDS solubility than that from poor bread making flour. Differences 194 in extraction methods, type of flour (cultivar, growing season, and location) and milling conditions 195 could account for differences in protein solubility. 
The amount of SDS-extractable proteins increased as mixing temperature decreased for SWF 197 dough (Fig. 2A). However, no significant $(\mathrm{p} \leq 0.05)$ differences were observed between SDS198 solubility in SWF dough at 15 and 30 or $4^{\circ} \mathrm{C}$. The increased solubility at lower temperatures could 199 be due to protein depolymerization as a result of the long mixing time, which could lead to lower 200 molecular weight development through protein disaggregation (Weegels et al 1997).

201 At low temperature $\left(4\right.$ and $\left.15{ }^{\circ} \mathrm{C}\right)$, addition of DTT to the SDS solution used for protein 202 extraction did not result in a significant increase $(\mathrm{p} \leq 0.05)$ in protein solubility, indicating that SWF 203 dough samples were stabilized by hydrophobic interactions. This could be due to breakdown of 204 disulfide linkages as a result of the long mixing times (Weegels et al 1997) or to lack of formation of 205 disulfide linkages from sulphydryls because of the low temperature (Hayta and Schofield 2004). On 206 the other hand, the significant $(\mathrm{p} \leq 0.05)$ increase in the amount of soluble proteins in presence of 207 DTT in the dough at $30^{\circ} \mathrm{C}$ indicates that this temperature promoted the formation of covalent 208 interactions. Moreover, at low temperature, the amount of proteins remaining insoluble in SDS+DTT 209 was significantly $(\mathrm{p} \leq 0.05)$ higher compared to dough mixed at $30{ }^{\circ} \mathrm{C}$. Dough mixing at temperature $210 \leq 15^{\circ} \mathrm{C}$ seems to promote the formation of macromolecular aggregates that do not solubilize easily 211 under the conditions used in this study, regardless of the presence of DTT. Indeed, low temperatures 212 were associated with an increase in the amount of unextractable fraction, which has been found to be 213 strongly correlated with dough strength and bread quality (Weegels et al 1996; Don et al 2003).

214 As for dough from HWF, there was not a clear trend in protein solubility changes with 215 mixing temperature (Fig. 2 B). A significant $(\mathrm{p} \leq 0.05)$ increase in SDS-extractable proteins was 216 observed when the mixing temperature was decreased from 30 to $15^{\circ} \mathrm{C}$. However, SDS-protein 217 solubility of dough samples mixed at $4{ }^{\circ} \mathrm{C}$ was comparable to that of the dough samples mixed at 15 $218{ }^{\circ} \mathrm{C}$ and $30{ }^{\circ} \mathrm{C}$. The SDS-DTT protein solubility of dough followed the trend observed for SWF. The 
$21930^{\circ} \mathrm{C}$ mixed dough sample showed significant difference $(\mathrm{p} \leq 0.05)$ between SDS-protein solubility 220 and SDS-DTT solubility, an indication that covalent interaction is the gluten network stabilizing 221 force in the dough. However, at low temperatures $\left(4\right.$ and $\left.15^{\circ} \mathrm{C}\right)$, there was no significant difference $222(\mathrm{p} \leq 0.05)$ between SDS and SDS-DTT protein solubility, suggesting that hydrophobic interactions 223 are the dominant force in the gluten network. Reasons given for similar observations in SWF would 224 suffice in explaining the observations in $\mathrm{HWF}$ dough. That is, dough mixing at temperatures $\leq 15^{\circ} \mathrm{C}$ 225 promoted the formation of insoluble macromolecular aggregates under the conditions of the study. 226 This is evidenced in the decreasing SDS-DTT protein solubility for the mixed doughs at 30, 15, and $227 \quad 4^{\circ} \mathrm{C}$ which were $961.02 \pm 12.84,529.01 \pm 65.34$ and $404.51 \pm 166.67 \mathrm{mg} / \mathrm{g}$ protein respectively. 228 229

Readily Accessible and SDS-Accessible Thiols. The content of readily accessible and SDSaccessible thiols in dough from SWF and HWF are shown in Fig. 3A and Fig. 3B, respectively. 231 When doughs were mixed at $30^{\circ} \mathrm{C}$ (standard temperature), the readily accessible thiols in both SWF $232(7.02 \pm 0.1 \mu \mathrm{mol} / \mathrm{g}$ protein) and HWF $(7.05 \pm 1.8 \mu \mathrm{mol} / \mathrm{g}$ protein) doughs were comparable to free 233 thiols levels in extracted gluten reported by others (Koehler 2003a,b; Gomez et al. 2011). However, 234 SWF dough showed significantly $(\mathrm{p} \leq 0.05)$ higher SDS-accessible thiols than HWF (Fig. 3A and 235 3B), in agreement with Jazaeri et al (2015). In general, in the presence of SDS, the thiol content 236 showed a marked increase. Indeed, thiols buried within protein structures (or a protein aggregate) 237 may become available to suitable reagents only upon protein denaturation by physical or chemical 238 agents (Iametti et al 2013).

239 Mixing temperature did not affect the levels of readily accessible thiols in SWF doughs (Fig $2403 \mathrm{~A})$. As for SDS-accessible thiols, significant $(\mathrm{p} \leq 0.05)$ differences were measured among samples, 241 but without a clear trend. Indeed, SDS-accessible thiols in the dough mixed at $30{ }^{\circ} \mathrm{C}$ were higher 242 than those of the one mixed at $15^{\circ} \mathrm{C}$, but lower than when mixing at $4{ }^{\circ} \mathrm{C}$. The marked SDS- 
243 dependent increase in accessible thiols observed for SWF dough mixed at $4{ }^{\circ} \mathrm{C}$ indicates that 244 disrupting of hydrophobic interactions and the consequent destabilization of the structure resulted in 245 the exposure of a considerable amount of thiol groups (Iametti et al 2006). These results confirm the 246 protein solubility data (Fig. 2A) that at low temperature SWF dough was characterized by 247 hydrophobic interactions. The low protein solubility in presence of DTT and the high amount of 248 unextractable proteins (Fig. 2A) at $4^{\circ} \mathrm{C}$ suggest the formation of intermolecular disulfide bonds that 249 promote formation of large and insoluble aggregates (Lagrain et al 2007), where accessibility to the 250 polar disulfide reducing agent DTT may be difficult even when SDS is present, at least when 251 solubility studies are carried out at room temperature as it was the case here.

252 HWF dough samples exhibited a different trend in thiol changes as mixing temperature 253 decreased (Fig. 3B) compared to SWF. Unlike SWF, the readily accessible thiols in HWF dough 254 responded to temperature changes. While the $15^{\circ} \mathrm{C}$ dough showed lower levels of readily accessible 255 thiols than at $30^{\circ} \mathrm{C}$, the $4^{\circ} \mathrm{C}$ dough had a slightly higher but insignificant level than at $30^{\circ} \mathrm{C}(7.54 \pm$ 2560.9 vs $7.05 \pm 1.8 \mu \mathrm{mol} / \mathrm{g}$ protein). With respect to SDS-accessible thiols, their levels in the dough 257 increased as mixing temperature decreased. This indicates maximum formation of disulfide bonds at 258 the standard mixing temperature of $30^{\circ} \mathrm{C}$, in agreement with changes in protein solubility as due to 259 the addition of disulfide-reducing agents (Fig. 2B). In addition, the increased levels of SDS260 accessible thiols in the dough mixed at $4^{\circ} \mathrm{C}$ and $15^{\circ} \mathrm{C}$ may be due to the long mixing time (Table I) 261 that possibly resulted in cleavage of disulfide bonds or exposure of thiols that were buried in 262 inaccessible portions of protein aggregates, but were made accessible by the detergent treatment 263 (Iametti et al 2006). 
265 State of water in dough. The changes in the structural and energy states of water as affected by mixing 266 temperature were characterized as reported by Bock et al (2013). The difference spectra obtained by 267 subtracting the $\mathrm{H}_{2} \mathrm{O}-\mathrm{D}_{2} \mathrm{O}$ reference spectrum $\left(45-50 \% \mathrm{H}_{2} \mathrm{O}-\mathrm{D}_{2} \mathrm{O}\right.$, according to the dough moisture in 268 Table I) is shown in Fig. 4. Dough samples exhibited two absorption bands; one centered at around 3580 $269 \mathrm{~cm}^{-1}$ and the other at around $3160 \mathrm{~cm}^{-1}$, and a negative trough at $3400 \mathrm{~cm}^{-1}$, regardless the mixing 270 temperature. Based on previous studies, the positive peak in the difference spectrum at $3600 \mathrm{~cm}^{-1} \mathrm{can} \mathrm{be}$ 271 assigned to $\mathrm{OH}$ stretch vibration of monomeric non-hydrogen-bonded water molecules and some 272 hydrogen-bonded water dimmers, whereas the peak at around $3160 \mathrm{~cm}^{-1}$ can be assigned to water 273 populations hydrogen-bonded to gluten network. The negative trough area represents fraction of water that 274 has been transmuted from small hydrogen-bonded cluster states $\left(3400 \mathrm{~cm}^{-1}\right)$ to other structural and energy 275 states represented by the absorption bands at $3160 \mathrm{~cm}^{-1}$ and $3580 \mathrm{~cm}^{-1}$ (Bock et al 2013).

In SWF doughs, mixing temperature seemed not to affect the monomeric non-hydrogen-bonded 277 water molecules, since the related peak was centered at around $3580 \mathrm{~cm}^{-1}$, regardless the mixing 278 temperature. On the other hand, the peak related to water populations hydrogen-bonded to the dough 279 slightly shifted from 3163 to $3158 \mathrm{~cm}^{-1}$ as mixing temperature decreased from $30^{\circ} \mathrm{C}$ to $4^{\circ} \mathrm{C}$, suggesting 280 that the hydrogen bonds of this structured water subpopulation was likely more rigid and more structured 281 in the sample at $4^{\circ} \mathrm{C}$ compared to the control dough $\left(30^{\circ} \mathrm{C}\right)$.

282 In the case of HWF, the $\mathrm{OH}$ stretch peak shifted to higher frequencies (from 3566 to $3585 \mathrm{~cm}^{-1}$ ) as 283 the mixing temperature decreased from $30^{\circ} \mathrm{C}$ to $4^{\circ} \mathrm{C}$, suggesting a decrease in the number of hydrogen 284 bonds per water molecule or increased distortion of the bonds in HWF dough mixed at low temperature. 285 Typically, water strongly bonded via hydrogen bonding to functional groups in polymer networks requires 286 less energy (low frequency) for $\mathrm{OH}$ stretch vibration. The stronger the hydrogen bond strength, the greater 287 is the shift of $\mathrm{OH}$ stretch absorption to a lower frequency (Bock et al 2013). Intensity of the OH stretch 
288 peak followed the order $15^{\circ} \mathrm{C}>30^{\circ} \mathrm{C}>4^{\circ} \mathrm{C}$, indicating that the monomeric water molecules increased when 289 dough was mixed at $15^{\circ} \mathrm{C}$ but decreased when the dough was mixed at $4{ }^{\circ} \mathrm{C}$. This could interact with thiol 290 groups through hydrogen bonding and affect their availability for detection and may be part of the reason 291 behind the least amount of readily accessible thiols found in the dough mixed at $15^{\circ} \mathrm{C}$ (Fig. $3 \mathrm{~b}$ ). Although the 292 intensity of the $3160 \mathrm{~cm}^{-1}$ band varied with mixing temperature $\left(4^{\circ} \mathrm{C}\right)$, the peak position of the band did 293 not change, indicating that the energy state of this population of water was not affected by the moisture 294 content of dough, as confirmed by the protein conformation data (see Fig. 5). Unexpectedly, despite a 295 decrease in the intensity of the structured water peak, the intensity of the free water peak did not decreased 296 but rather increased at low mixing temperature.

297 It has been reported that even if hydrogen bonds are weak, they play a key role in determining the 298 physical properties of dough (Tkachuk and Hlynka, 1968), as demonstrated by the increase in stability 299 when dough was mixed al low temperature (Fig 1). The results were in agreement with the protein 300 aggregate formation, since the increase in water structure can be responsible for increased non-covalent 301 interactions (Fig. 2). In addition, it has been reported that structured water occurs at the hydrophobic 302 patches on the protein surface (Zelent et al, 2009), in agreement with protein aggregation in Fig. 2. 303 Investigating the impact of dough moisture on the state of water, Bock et al (2013) also highlighted a shift 304 in frequency of the structured water peak, as the moisture content of the dough was increased. However, 305 in the humidity range of $40-45 \%$, which was very similar to the dough moisture in our study (Table I), the 306 impact of dough moisture on the state of water was much greater than what was detected in Fig 4a, 307 suggesting that the mixing temperature affected the way the flour interacts with water.

Protein Conformation. The secondary structure contents of protein in dough samples are shown in 310 Fig. 5. In both SWF and HWF dough mixed at $30^{\circ} \mathrm{C}$, the structures were in the order $\beta$-sheets $>\beta$ - 
311 turns $>$ random $>\alpha$-helix, in agreement with previous studies (Jazaeri et al 2015; Bock and 312 Damodaran 2013; Pézolet et al 1992; Li et al 2006). In weak doughs, high levels of $\beta$-sheets 313 structures have been associated with protein hydrophobicity (Jazaeri et al 2015). In strong doughs, 314 formation of $\beta$-sheets seems to be facilitated by disulfide linkages (Jazaeri et al 2015), which is in 315 agreement with the protein solubility data in presence and absence of reducing agent (Fig 2b) and 316 with the thiols content (Fig 3b).

317 Dough mixing temperature affected protein conformation differently in the two flours (Fig. 318 5). In SWF dough, $\beta$-sheet structures significantly $(p \leq 0.05)$ decreased with a gain in $\beta$-turn 319 structures, as temperature decreased (Fig. 5A). However, random and $\alpha$-helix structures were not 320 significantly $(\mathrm{p} \leq 0.05)$ affected by changes in mixing temperature. It has been reported that any 321 change in wheat dough that causes a greater hydration of dough is responsible for an increase in $\beta$ 322 turn content at the cost of decrease in $\beta$-sheet content up to $45 \%$ moisture content (Bock et al 2013). 323 On the other hand, $\beta$-turn structures subsequently dropped at 50\% moisture content (Bock et al 324 2013). In the present study, as mixing temperature decreased, the moisture content of the dough 325 increased from 42.1 to $46.6 \%$ (Table I) and the $\beta$-turn structures - regions where there are groups of 326 polymer solvent interactions (Belton 1999) increased, whereas the $\beta$-sheet structures - regions where 327 there are groups of polymer surface interactions (Belton 1999) decreased. Decreasing $\beta$-sheet 328 structures with temperature might suggest a weakening of hydrophobic interactions, as mixing 329 temperature decreased.

330 In SWF dough, the $\beta$-sheet to turn ratio decreased as the mixing temperature decreased (1.55, 3312.36 , and 3.19 for 4,15 , and $30^{\circ} \mathrm{C}$, respectively; data not shown), suggesting the formation of a more 332 hydrated system, consistent with the slightly decreasing shift in peak frequency for water population 333 strongly bonded to dough (Fig. 4A). Interestingly, the $\beta$-sheet to turn ratio for SWF dough at $4^{\circ} \mathrm{C}$ 
334 was comparable with those of $\mathrm{HWF}$ dough at $30^{\circ} \mathrm{C}(1.62$; data not shown) which also showed the 335 least amount of free water (Fig. 4B).

In HWF dough, a decrease in mixing temperature caused only a slight increase in $\beta$-sheet 337 structure, whereas $\beta$-turn, $\alpha$-helix and random structures were not affected by temperature changes 338 (Fig 5B). This may indicate that gluten proteins in HWF dough are not susceptible to change in their 339 conformation at the low temperatures, unlike those in SWF. This is supported by the fact that the 340 SDS protein solubility did not show a consistent trend as mixing temperature decreased from $30^{\circ} \mathrm{C}$ 341 to $4^{\circ} \mathrm{C}$ (Fig. 2B). These results are in agreement with those of Bock et al (2013) who found that 342 weak flour dough was unable to maintain its secondary structural distribution upon bran addition 343 compared to the strong flour dough.

344 Protein conformation may therefore be of little relevance in protein stabilization in HWF 345 dough when mixed at lower temperatures $\left(4^{\circ} \mathrm{C}\right.$ and $\left.15^{\circ} \mathrm{C}\right)$. On the other hand, given the increase in 346 SDS-accessible thiols as mixing temperature decreased (Fig. 3B) and the corresponding increase in 347 SDS protein solubility (Fig 2B), it is possible that the longer mixing times associated with low 348 temperature (Table I) enhanced cleavage of intermolecular disulfide linkages in high molecular 349 weight glutenin subunits; these events have been reported to occur at higher levels in HWF (Payne et 350 al 1981, 1987).

353 From the results of this study on the effect of mixing temperatures on protein structural 354 characteristics of SWF and HWF flour doughs, three main conclusions can be drawn. First, at 355 mixing temperature lower than $30^{\circ} \mathrm{C}$, dough from SWF flour showed a similar rheology as dough 356 from HWF flour mixed at standard temperature. Second, network formation in dough samples mixed 357 at $4{ }^{\circ} \mathrm{C}$ and $15^{\circ} \mathrm{C}$ appear to be driven more by hydrophobic interactions, whereas the network 
358 formed at $30{ }^{\circ} \mathrm{C}$ is mainly characterized by covalent interactions. Finally, the effect of low mixing 359 temperature is different at the molecular level between the HWF and SWF flours considered in this 360 study. In particular, in HWF flour mixing temperature strongly affected only the SDS-accessible 361 thiols content, whereas, in SWF flour mixing temperature resulted in changes in all the molecular 362 parameters considered in this study.

LITERATURE CITED

365

366

AACC International. Approved methods of Analysis. 11th Ed. Method10-10.03. Optimized straight 367 dough bread-making method. Approved November 3, 1999. AACCI: St Paul, MN, USA. http://dx.doi.org/10.1094/AACCIntMethod-10-10.03.

AACC International. Approved methods of Analysis. 11th Ed. Method 46-30.01.Crude Protein370 Combustion method. Approved November 3, 1999. AACCI: St Paul, MN, USA. http://dx.doi.org/10.1094/AACCIntMethod-46-30.01.

AACC International. Approved methods of Analysis. 11th Ed. Method 54-21.02. Rheological Behavior of Flour by Farinograph: Constant Flour Weight Procedure. Approved November 3, 1999. AACCI: St Paul, MN, USA. http://dx.doi.org/10.1094/AACCIntMethod-54-21.02.

Basaram, A and Gocmen, D. 2003. The effects of low temperature on dough rheology and bread properties. Eur Food Res Technol. 217:138 - 142

Belton, P. S. 1999. On the elasticity of wheat gluten. J. Cereal Sci. 29:103-107. 
381 Bock, J. E., Connelly, R. K., and Damodaran, S. 2013. Impact of bran addition on water properties 382 and gluten secondary structure in wheat flour doughs studied by Attenuated Total Reflectance Fourier Transform Infrared spectroscopy. Cereal Chemistry 90: 377-386.

Bonomi, F., Ferranti, P., and Mamone, G. 2014. Wheat flour chemistry and biochemistry. Pages 55385 74 in: Bakery Products Science and Technology. W Zhou and Y. H. Hui, eds. Wiley-Blackwell Press: Singapore.

387 Bonomi, F., D’Egidio, M. G., Iametti, S., Marengo, M., Marti, A., Pagani, M. A., and Ragg, E. M. 388 2012. Structure-quality relationship in commercial pasta: A molecular glimpse. Food Chem. $389 \quad 135: 348-355$.

390 Danno, G., and Hoseney, R. 1982. Effects of dough mixing and rheologically active compounds in 391 relative viscosity of wheat proteins. Cereal Chem. 59:196-198.

392 Don, C., Lichtendonk, W., Plijter, J. J., and Hamer, R. J. 2003. Glutenin macroplymer: A gel formed 393 by glutenin particles. J. Cereal Sci. 37:1-7

394 Eyer, P., Worek, F., Kiderlen, D., Sinko, G., Stglin, A., Simeon-Rudolf, V., and Reiner, E. 2003. 395 Molar absorption coefficients for the reduced Ellman reagent: reassessment. Anal. Biochem. $396 \quad 312: 224-227$.

397 Gomez, A., Ferrero, C., Calvelo, A., Anon, M. C., and Puppo, M. C. 2011.Effect of mixing time on 398 structural and rheological properties of wheat flour dough for bread making.Int. J. Food $399 \quad$ Properties. 14:583-598.

400 Graveland, A., Bosveld, P., Lichtendonk, W. J., and Moonen, J.H.E. 1980. Superoxide involvement 401 in the reduction of disulfide bonds of wheat proteins. Biochem. Biophys. Res. Comm. 93:1189402 1195. 
403 Hayta, M., and Schofield, J. D. 2004. Heat and additive induced biochemical transitions in gluten 404 from good and poor breadmaking quality wheats.J. of Cereal Sci. 40:245-256.

405 Iametti, S., Marengo, M., Miriani, M., Pagani, M. A., Marti, A., and Bonomi, F. 2013. Integrating 406 the information from proteomic approaches: A "thiolomics" approach to assess the role of thiols 407 in protein-based networks.Food Res. Int., 54:980-987.

408 Iametti, S., Bonomi, F., Pagani, M. A., Zardi, M., Cecchini, C and D’Egidio, M. G. 2006. Properties 409 of protein and carbohydrate fractions in immature wheat kernels. J. Agric. Food Chem. $410 \quad 54: 10238-10244$.

411 Jazaeri, A., Bock, J. E., Bagagli, M., P., Iametti, S., Bonomi, F., and Seetharaman, K. 2015. 412 Structural modifications of gluten proteins in strong and weak wheat dough during mixing. 413 Cereal Chem. 92:105-113.

414 Kieffer, R., Wieser, H., Henderson, M. H., and Graveland, A. 1998. Correlations of the breadmaking 415 performance of wheat flour with rheological measurements on a micro-scale. J. Cereal Sci. $416 \quad 27: 53-60$.

417 Koehler, P. 2003a. Concentrations of low and high molecular weight thiols in wheat dough as 418 affected by different concentrations of ascorbic acid.J. Agric. Food Chem. 51:4948-4953.

419 Koehler, P. 2003b. Effect of ascorbic acid in dough: Reaction of oxidized glutathione with reactive 420 thiol groups of wheat glutelin.J. Agric. Food Chem. 51:4954-4959.

421 Kuktaite, R., Larsson, H., and Johansson, E. 2004. Variation in protein composition of wheat flour 422 and its relationship to dough mixing behavior. J. Cereal Sci. 40:31-39.

423 Lagrain, B., Thewissen, B. G., Brijs, K., and Delcour, J. A. 2007. Impact of redox agents on the 424 extractability of gluten proteins during bread making.J. Agric. Food Chem.55:5320-5325. 
425 Li, W., Dobraszczyk, B. J., Dias, A., and Gi, M. 2006.Polymer conformation of wheat proteins and 426 gluten subfractions revealed by ATR-FTIR. Cereal Chem. 83:407-410

427 Lowry, O. H., Rosenbrough, N., J., Farr, A., Randall, R. J. 1951. Protein measurement with 428 Folinphenol reagent. J. Biol. Chem. 193:265-275.

429 MacRitchie, F. 1975. Mechanical degradation of gluten proteins during high-speed mixing of 430 doughs. J. Polym. Sci. 49:85-90.

431 Mecham, D.K., Cole, E. G. and Pence, J. W. 1965. Dough mixing properties of crude and purified 432 glutens. Cereal Chem. 42:409-420

433 Payne, P. I., Nightingale, M. A., Krattiger, A. F., and Holt, L. M. 1987.The relationship between 434 HMW glutenin subunit composition and the bread-making quality of British-grown wheat 435 varieties. J. Sci. Food Agric. 40:51-65.

436 Payne, P.I., Corfield, K. G., and Blackman, J. A. 1981. Correlation between the inheritance of 437 certain high molecular -weight subunits of glutenin and bread-making quality in progenies of 438 six crosses of bread wheat. J. Sci. Food Agric. 32:51-60.

439 Pézolet, M., Bonenfant, S., Dousseau, F., and Popineau, Y. 1992. Conformation of wheat gluten 440 proteins comparison between functional and solution states as determined by infrared $441 \quad$ spectroscopy.FEBS Letters, 299:247-250.

442 Robertson, G., Gregorski, K., and Cao, T. 2006. Changes in secondary protein structures during 443 mixing development of high absorption (90\%) flour and water mixtures. Cereal Chem. 83:136$444 \quad 142$.

445 Tanaka, K., and Bushuk, W. 1973. Changes in flour proteins during dough mixing. III. Analytical 446 results and mechanisms. Cereal Chem. 50:606-612. 
447 Thanhaeuser, S. M., Wieser, H., and Koehler, P. 2014. Correlation of quality parameters with the $448 \quad$ baking performance of wheat flours. Cereal Chem. 94:333-341.

449 Tkachuk, R., and Hlynka, I. 1968. Some properties of dough and gluten in D2O. Cereal Chem. $450 \quad 45: 80-87$.

451 Tsen, C.C. 1967. Changes in flour proteins during dough mixing. Cereal Chem. 44:308-317

452 Weegels, P. L., van de Pijpekamp, A. M., Gaveland, A., Hamar, R.J. and Schofield, J.D. 1996. 453 Depolymerization and repolymerization of wheat glutenin during dough processing. I. 454 Relationship between GMP content and quality parameters. J. Cereal Sci. 23: 103-111.

455 Weegels, P. L., Hamar, R.J. and Schofield, J.D. 1997. Depolymerization and repolymerization of 456 wheat glutenin during dough processing. II. Changes in composition. J Cereal Sci. 25:155-163.

457 Zelent, B., Bryan, M.A., Sharp, K.A., Vanderkooi, J.M. 2009. Influence of surface groups of 458 proteins on water studied by freezing/thawing hysteresis and infrared spectroscopy. Biophys. $459 \quad$ Chem. 141:222-230.

460 


\section{FIGURE LEGENDS}

462

463 Fig. 1. Mixing profiles of soft (A) and hard (B) wheat dough prepared at 4,15 and $30{ }^{\circ} \mathrm{C}$.

464

465 Fig. 2. Protein solubility of soft (A) and hard (B) wheat dough mixed at 4, 15 and $30{ }^{\circ} \mathrm{C}$. Values 466 with the same letters are not significantly different $(\mathrm{p} \leq 0.05)$.

467

468 Fig. 3. Readily accessible and SDS-accessible thiols of soft (A) and hard (B) wheat dough prepared at 4, 46915 and $30{ }^{\circ} \mathrm{C}$ mixing temperature. Values with the same letters are not significantly different $(\mathrm{p} \leq 0.05)$.

470

471 Fig. 4. ATR-FTIR difference spectra of soft (A) and hard (B) wheat dough prepared at various

472 mixing temperatures in the $\mathrm{OH}$ stretch region.

473

474 Fig. 5. Distribution of protein secondary structure forms in the dough from soft (a) and hard (b) wheat

475 prepared at various mixing temperatures. A separate ANOVA was run for each structure. Symbols

476 associated with different letters are significantly different (one-way ANOVA, LSD test, $\mathrm{p} \leq 0.05$ ). 
Table I.

Mixing properties of soft and hard wheat flours at various mixing temperatures

\begin{tabular}{|c|c|c|c|c|c|c|}
\hline & \multicolumn{3}{|c|}{$\begin{array}{c}\text { Soft wheat flour } \\
\text { (SWF) }\end{array}$} & \multicolumn{3}{|c|}{$\begin{array}{l}\text { Hard wheat flour } \\
\text { (HWF) }\end{array}$} \\
\hline & $4^{\circ} \mathrm{C}$ & $15^{\circ} \mathrm{C}$ & $3^{\circ} \mathrm{C}$ & $4^{\circ} \mathrm{C}$ & $15^{\circ} \mathrm{C}$ & $30^{\circ} \mathrm{C}$ \\
\hline $\begin{array}{l}\text { Dough moisture } \\
\qquad(\mathrm{g} / 100 \mathrm{~g})\end{array}$ & 46.6 & 46.3 & 42.1 & 49.3 & 46.5 & 44.0 \\
\hline $\begin{array}{l}\text { Water Absorption } \\
\text { (g/100g flour) }\end{array}$ & 68.7 & 61.5 & 55.5 & 81.4 & 74.2 & 64.7 \\
\hline $\begin{array}{l}\text { Dough Development Time } \\
\text { (min:s) }\end{array}$ & 09:40 & $05: 05$ & 01:01 & $16: 48$ & $12: 33$ & $02: 44$ \\
\hline $\begin{array}{l}\text { Stability } \\
\text { (min:s) }\end{array}$ & $10: 42$ & $10: 41$ & 01:33 & $15: 53$ & $13: 19$ & $15: 04$ \\
\hline
\end{tabular}




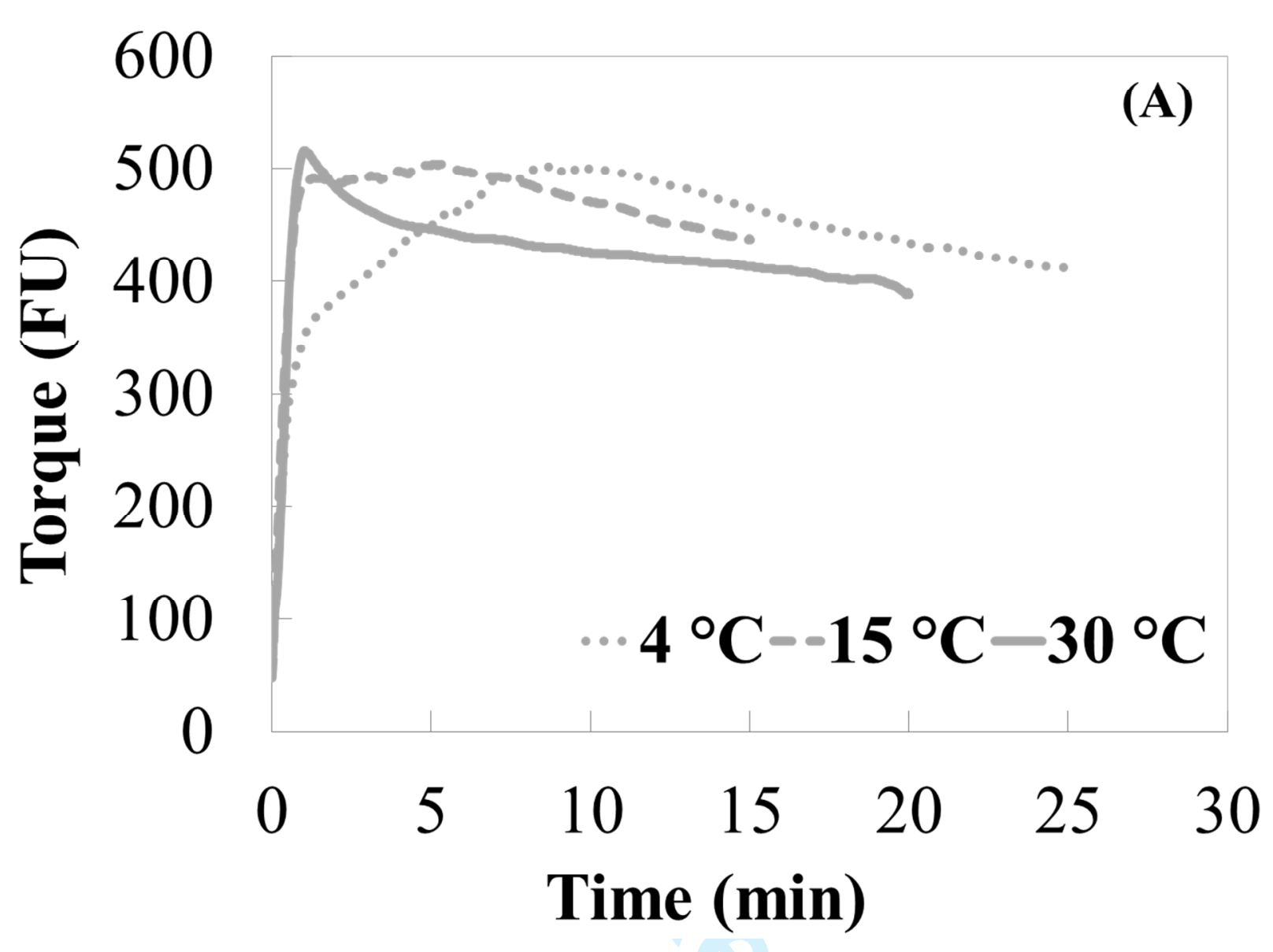




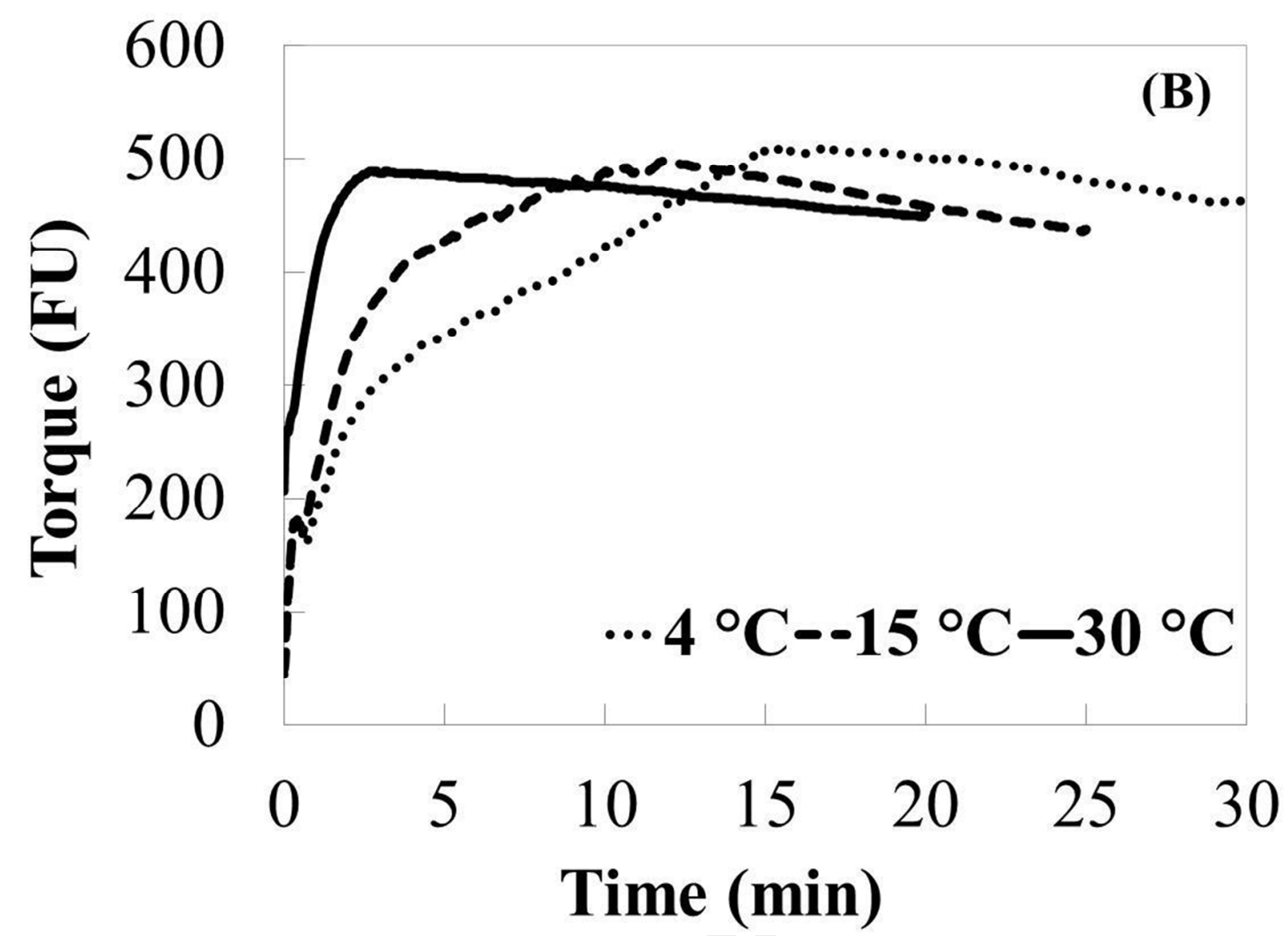

Fig. 1 


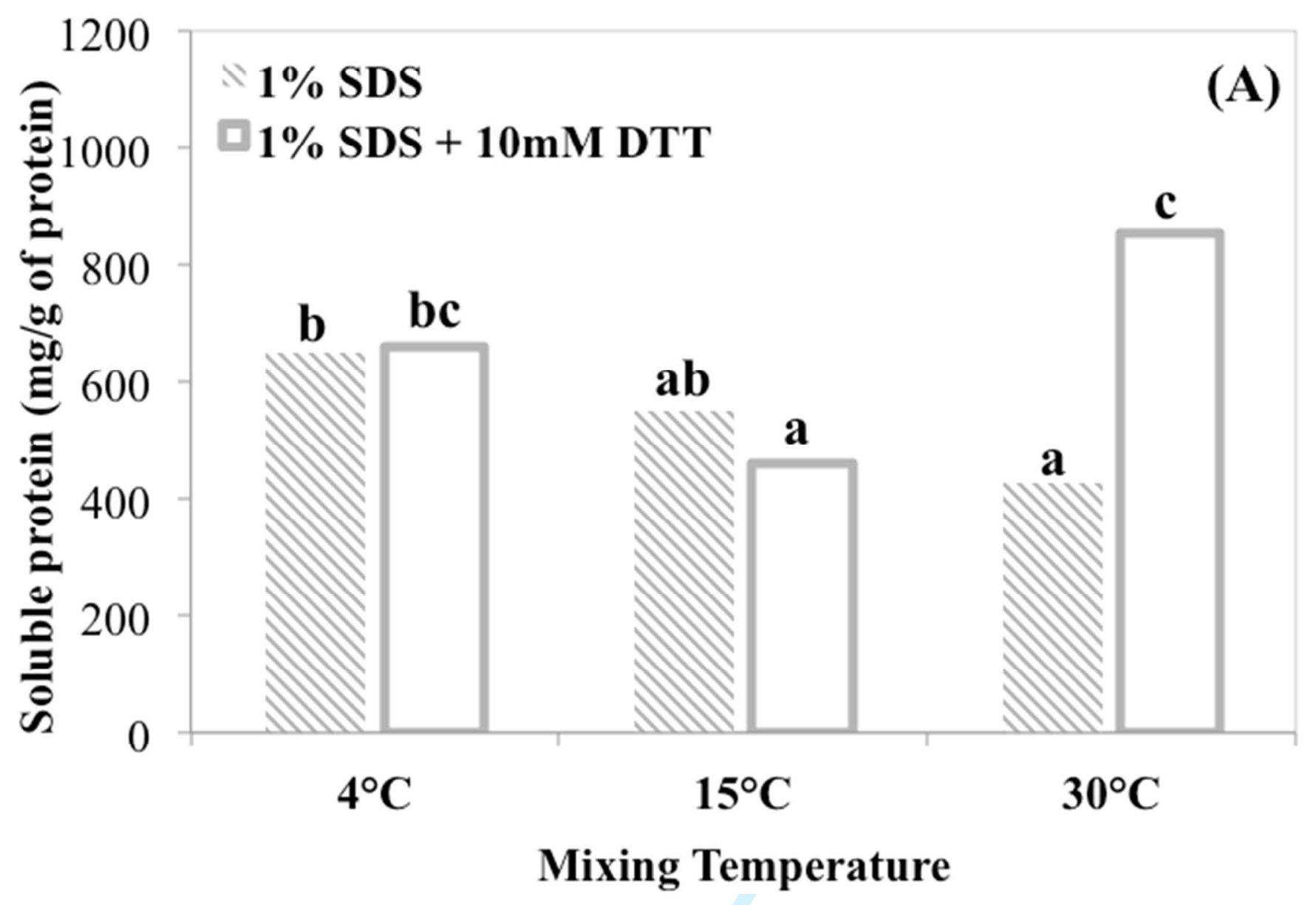




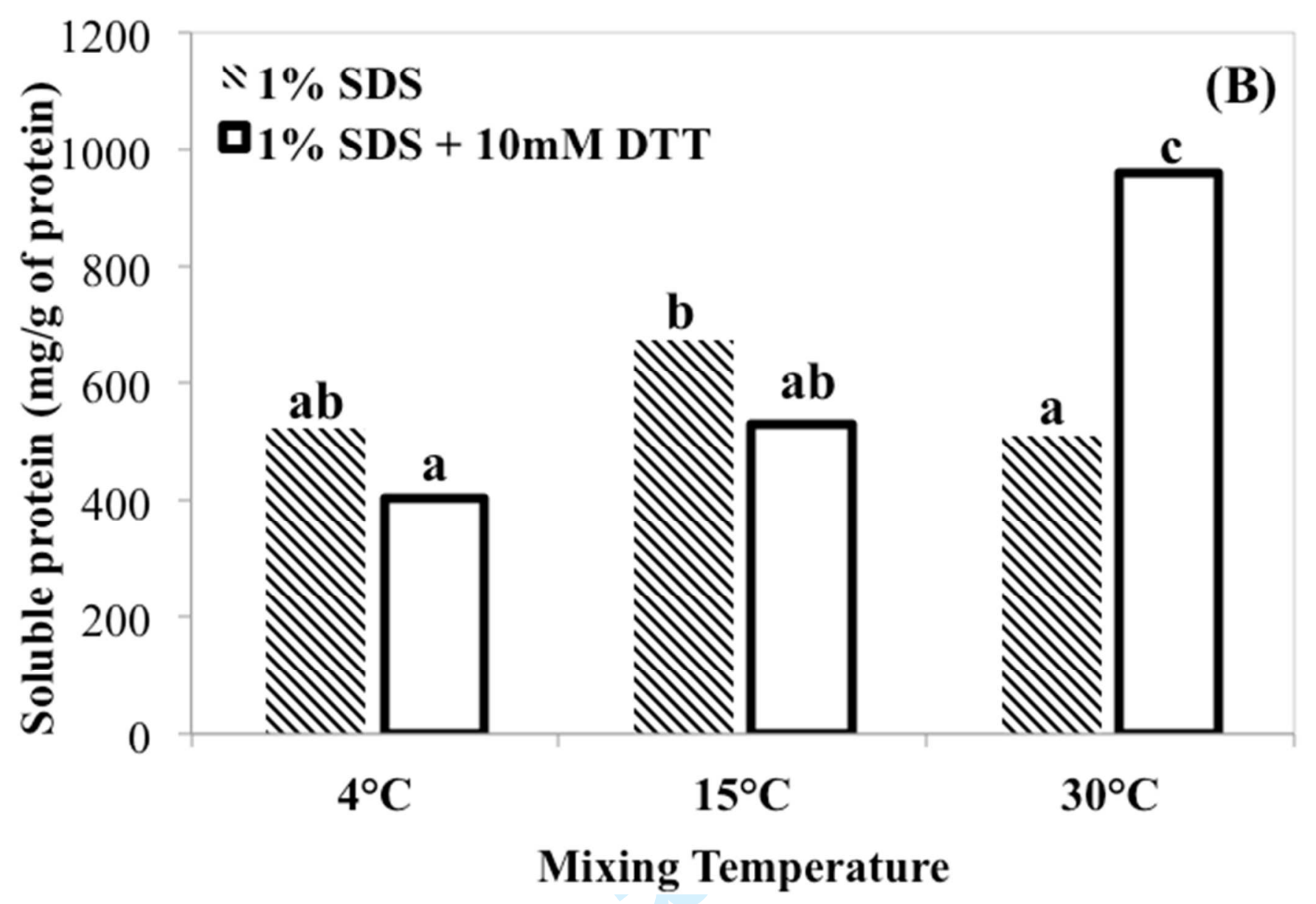

Fig. 2. 


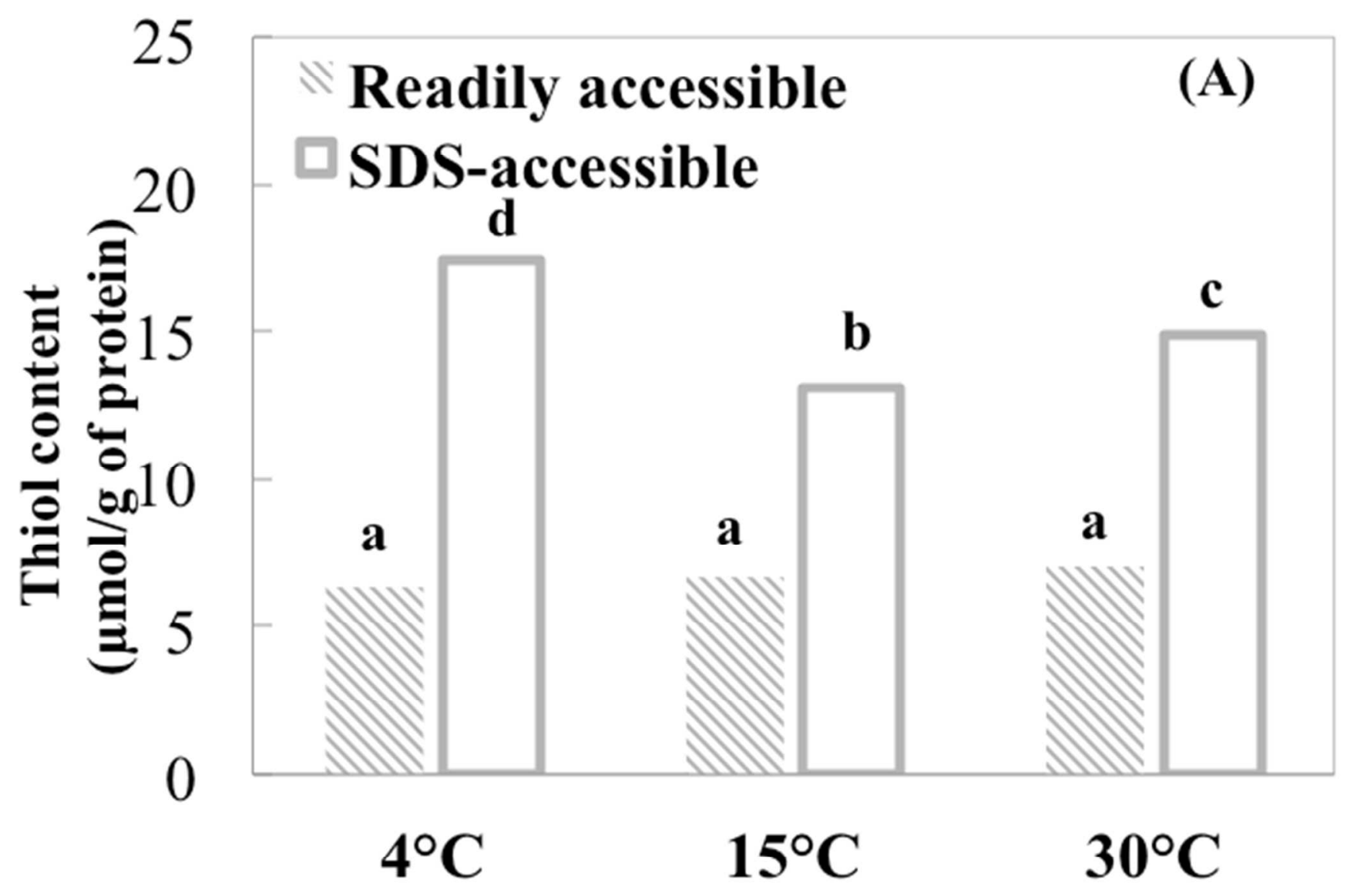




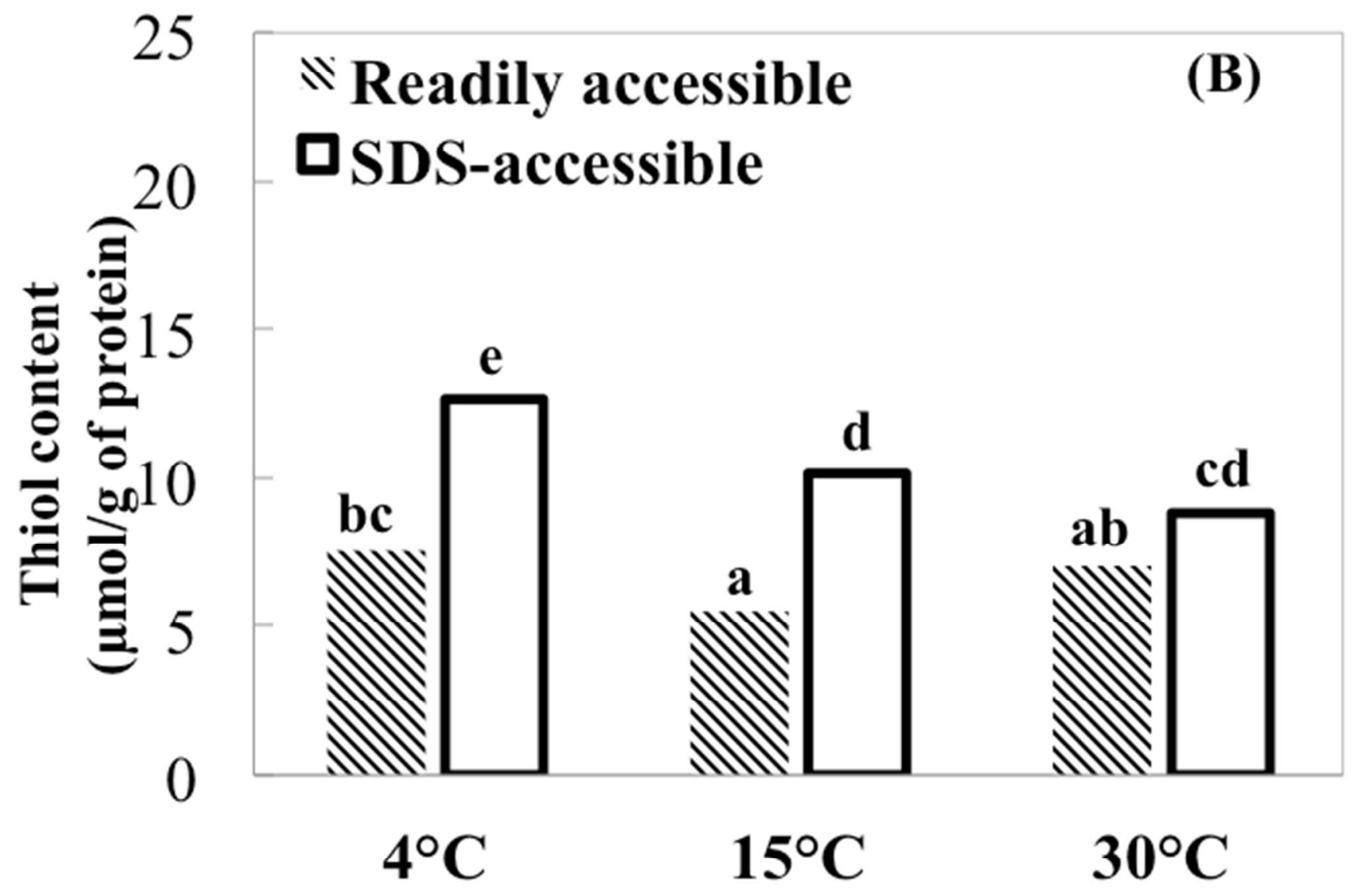

Fig. 3. 


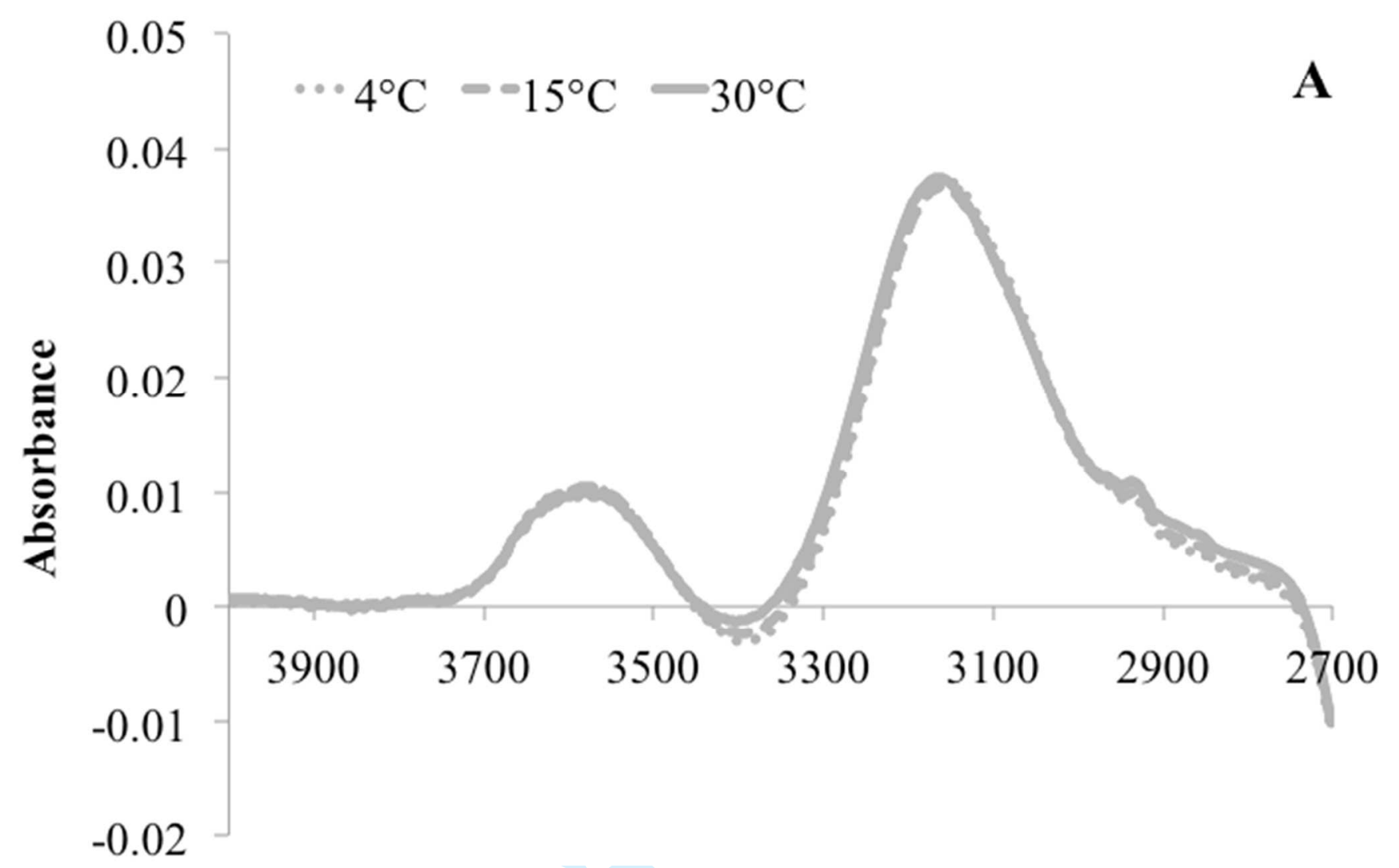




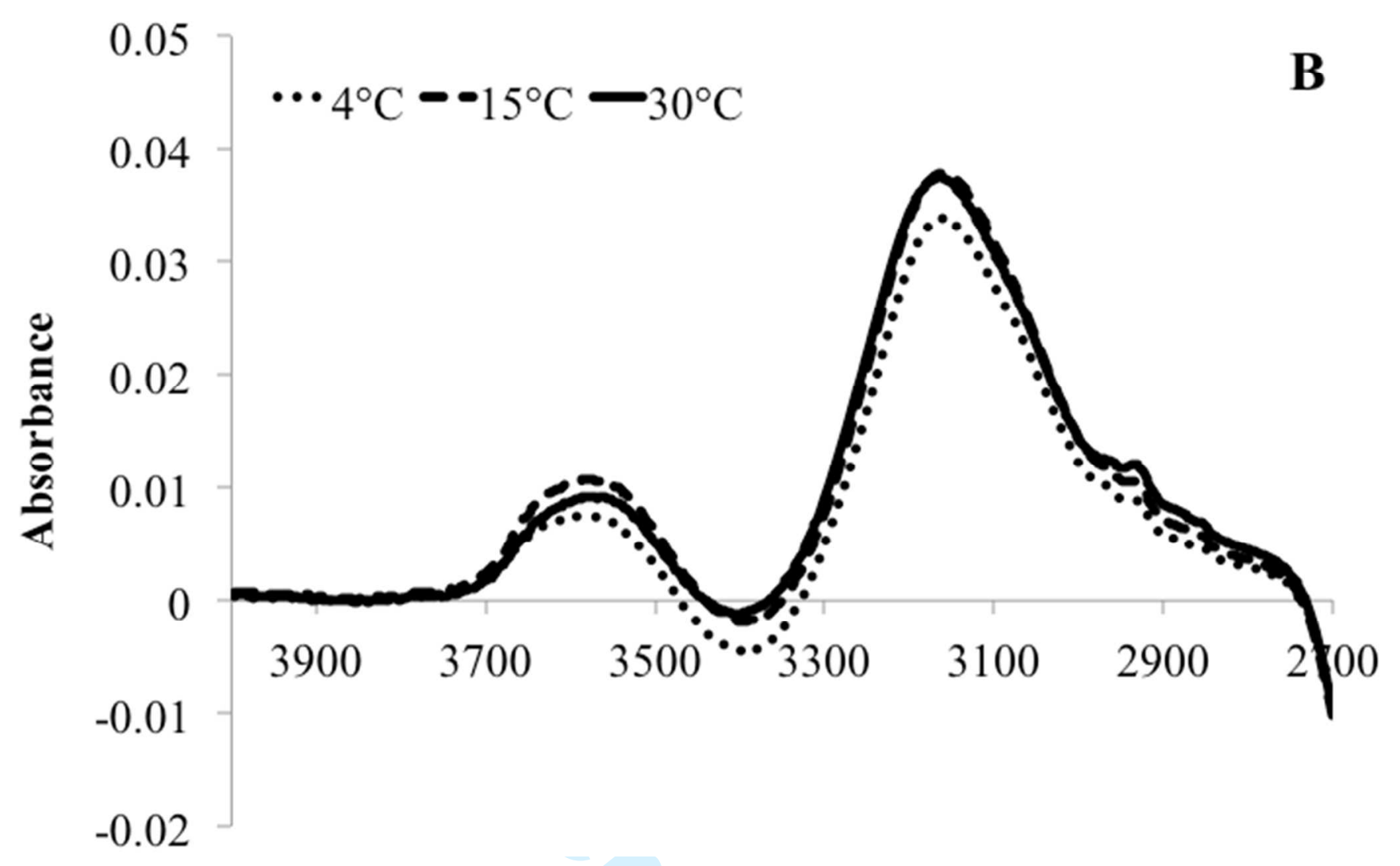

Fig. 4. 


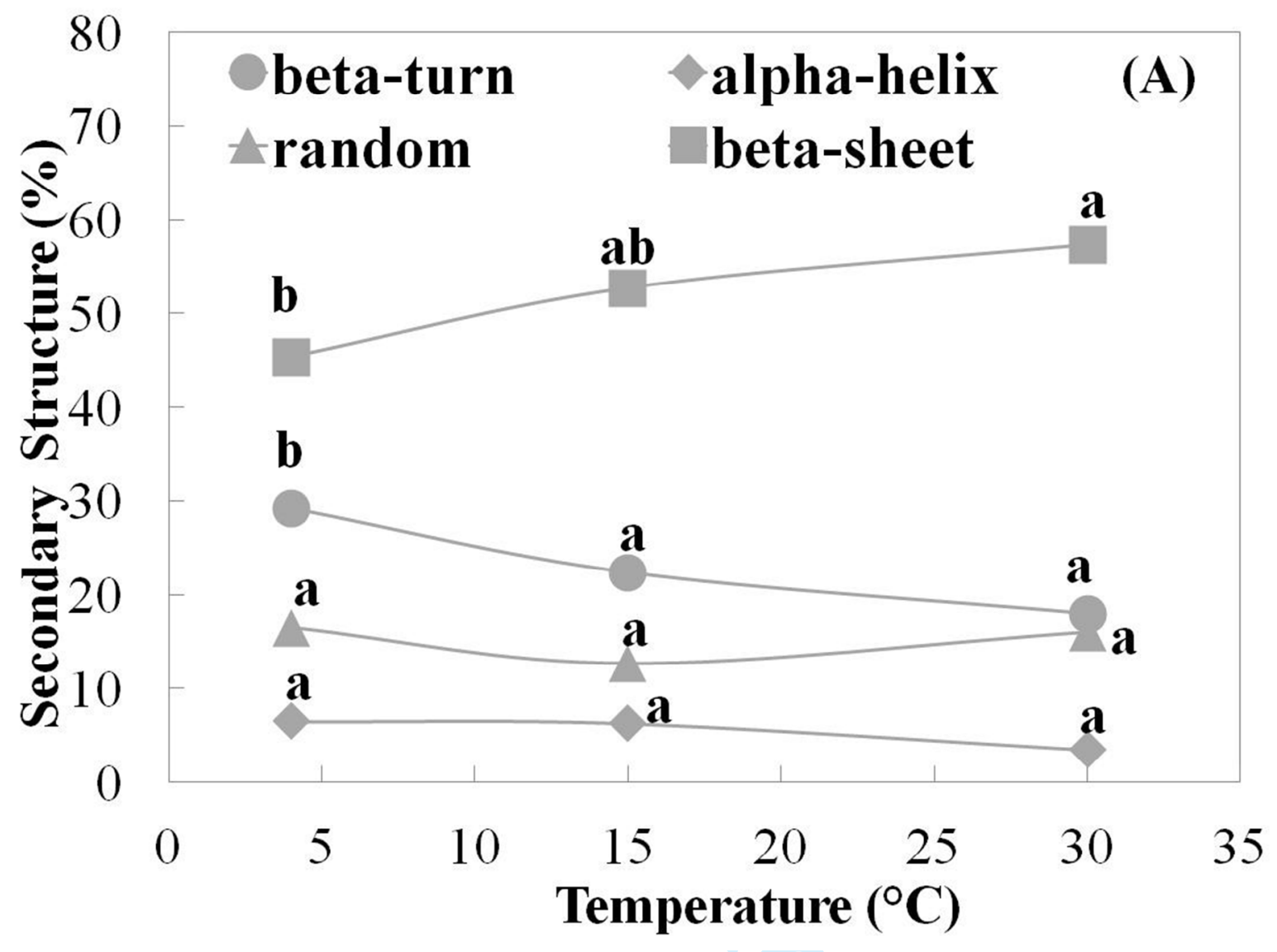




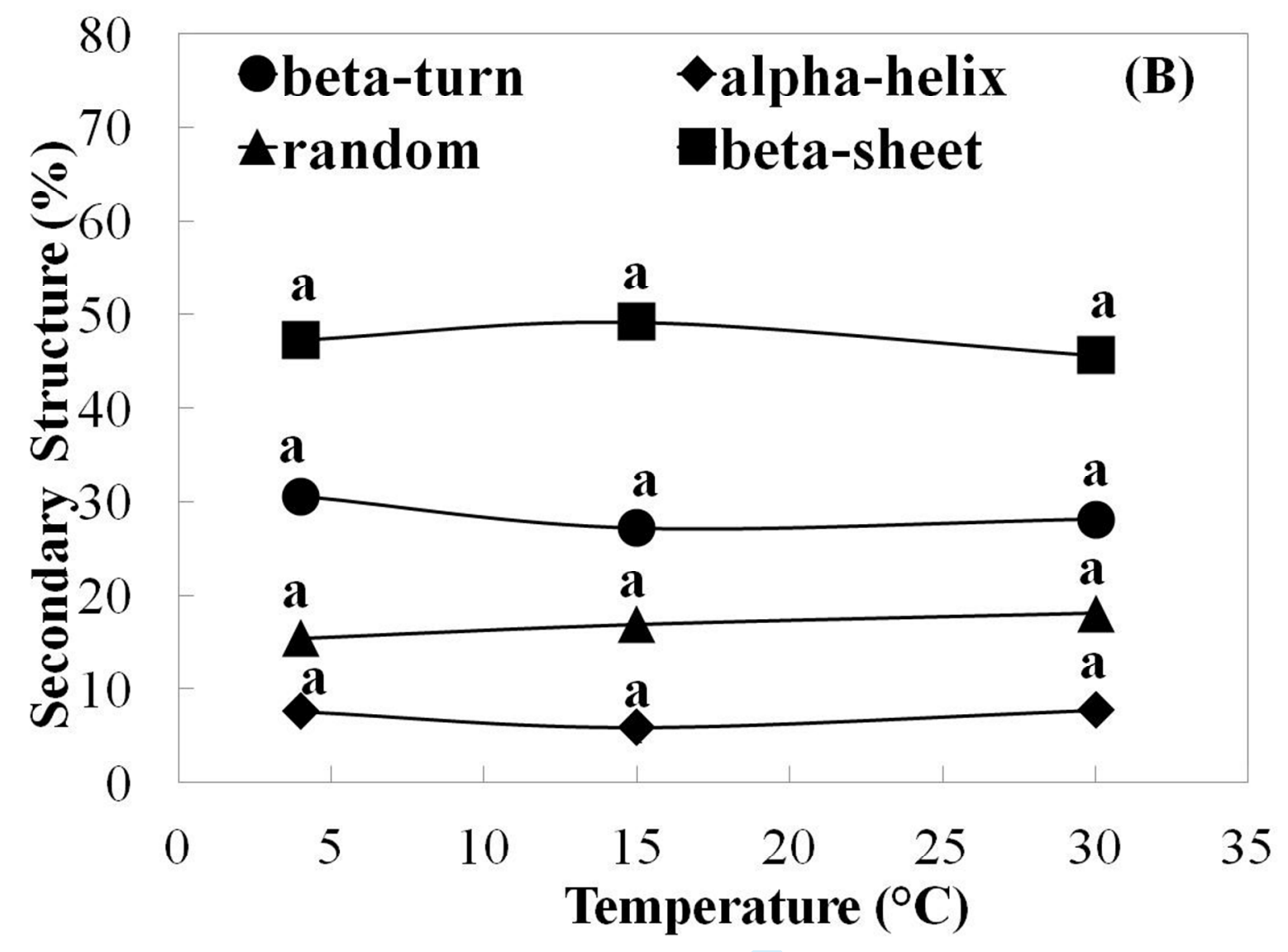

Fig. 5. 